\title{
Racism in The Novel The Hate U Give by Angie Thomas
}

\author{
Ni Wayan Yunitri*, I Made Rajeg, Sang Ayu Isnu Maharani \\ English Department, Faculty of Arts, Udayana University \\ [yuni230797@gmail.com] \\ *Corresponding Author
}

\begin{abstract}
This study was intended to find out the extrinsic elements that were exposed in the novel entitled "The Hate U Give", and to analyze how the story reflected the racism in America. The data of this study was taken from Angie Thomas's debut novel entitled "The Hate U Give. The data used in this study was in the form of sentences and words taken from dialogues and narration of the novel. This study applied documentation method, and the data was analysed by applying two theories; the extrinsic approach that was proposed by Wellek and Warren and the sociological approach proposed by Laurensen and Swingewood. Furthermore, the analysis was presented using the informal method. The result of the analysis showed that the five extrinsic elements proposed by Wellek and Warren namely; Biography, Psychology, Society, Ideas, and Other Forms of Art were found in the novel, and the author was influenced by the extrinsic elements in writing the novel. Furthermore, it was found that the racism in America was reflected through a realistic depiction written based on the real phenomenon happened in America.
\end{abstract}

Keywords: Literature, Extrinsic Elements, Racism

\begin{abstract}
Abstrak
Penelitian ini bertujuan untuk menemukan unsur ekstrinsik yang terdapat pada novel karya Angie Thomas yang berjudul "The Hate U Give, dan juga untuk menganalisis bagaimana novel tersebut merefleksikan rasisme di Amerika. Data dari penelitian ini diambil dari novel karya Angie Thomas yang berjudul "The Hate U Give". Data yang digunakan dalam penelitian ini berbentuk kalimat dan kata-kata yang diambil dari dialog dan narasi novel tersebut. Penelitian ini mengimplementasikan metode dokumentasi dimana data yang di dapat dianalisis menggunakan teori pendekatan ekstrinsik dari Wellek and Warren, dan pendekatan sosiologi dari Laurensen dan Swingwood. Data kemudian di presentasikan menggunakan metode informal. Hasil dari penelitian ini menunjukan bahwa lima unsur ekstrisik yang dikemukakan oleh Wellek and Warren, yaitu; Biografi, psikologi, keadaan masyarakat, ide, dan bentuk-bentuk lain dari seni ditemukan di dalam novel, dan kelima unsur ekstrinsik tersebut terbukti telah mempengaruhi sang penulis dalam menulis novel tersebut. Selanjutnya, ditemukan bahwa rasisme di Amerika terefleksikan melalui penggambaran realistis yang ditulis berdasarkan kejadian-kejadian nyata yang terjadi di Amerika.
\end{abstract}

Kata kunci: Literatur, Unsur Ekstrinsik, Rasisme 


\section{Background of the Study}

Learning literature is the same as learning the life itself as literature can reflect the reality. A work of literature often created based on the reality especially those around the writer's life. For that reason, the writers are mostly influenced by those elements around them when they create their work. Hence, in order to have a better understanding of a literary work, the external factors that may influence the creation of a certain literary work need to be taken into account.

Through the time, literature has been used not only for the purpose of entertaining the readers, but also to give critics to almost every aspect of life.. This is why a problem like social issues is commonly found in literature; those social issues include injustice, racism, inequality, violence, and others .Racism is one of the social issues that commonly found in some literatures, like in the poem entitled "Let America be America Again" by Langston Hughes. According to Smedley, racism also called racialism is any action, practice, or belief that reflects the racial worldview-the ideology that humans may be divided into separate and exclusive biological entities called "races", and that some races are innately superior to others. Another story that reflects racism is "The Hate U Give" By Angie Thomas.

This study analyzes what extrinsic elements are exposed in the story of "The Hate U Give" and how the racism in America is reflected in the story. The analysis of the extrinsic elements is important in order to understand more about the story by trying to find the external factors that influence the author in creating this particular novel entitled "The Hate U Give". Furthermore, the analysis of the racism in the novel is done in order to prove that a work of literature can reflect the real situation of the world, and to show that Black people in America are still experiencing injustice because of their race.

\section{Problems of the Study}

Based on the background of the study above, there are two questions to be discussed as follows:

a. What extrinsic elements are exposed in the novel entitled "The Hate U Give" by Angie Thomas?

b. How the racism in America is reflected in the novel entitled "The Hate U Give" by Angie Thomas?

\section{Aims of the Study}

With regards to the problem of study mentioned above, this study is aimed at:

a. To find out the extrinsic elements exposed in the novel entitled "The Hate U Give" by Angie Thomas.

b. To analyze how the racism in America is reflected in the novel entitled "The Hate U Give" by Angie Thomas.

\section{Research Method}

This study is a literary study that focuses on analyzing the racism in the debut novel of Angie Thomas; therefore, library research is applied. This part includes Data Source, Method and Technique of Collecting Data, Method and Technique of Analyzing Data, and Method and Technique of Presenting Analysis.

\subsection{Data Source}

The source of the data for this study is Angie Thomas's debut novel entitled "The Hate U Give", published by Walkers Book Ltd, 87 Vauxhall Walk, London, in 2017. This novel contains 438 pages, consisting of 26 chapters. The analysis is focused on the sentences and words taken from the narration and dialogue of the novel that shows the influence of the extrinsic elements and sentences and words of the novel's narration and dialogue that indicates 
racism. This novel is chosen because the story is about the injustice experienced by the black people in America which is an indication of racism.

\subsection{Method and Technique of Collecting Data}

The data was collected using a documentation method that usually used to collect the data from documents like book, notes, and others. The technique of collecting data was done by using these following steps: The first step was reading the novel carefully then continued by highlighting the sentences and words taken from the narration and dialogue of the novel that showed the influence of the extrinsic elements and indicated racism. The next step was taking note of the sentences and words that showed the influence of the extrinsic elements and the sentences and words that indicated racism and the last step was identifying the data in order to find out the extrinsic elements that influenced the creation of the novel, and how the novel reflected the racism in America.

\subsection{Method and Technique of Analyzing Data}

In analyzing the data, this study used qualitative method as the data of this study was non-numerical data. First, the collected data was identified and classified according to extrinsic approach proposed by Wellek and Warren in 1977 to find out the extrinsic elements exposed in the novel, and then it was analyzed using sociological approach proposed by Laurenson and Swingewood in 1972 that examined the literature in the cultural, economic, and political context in which it was written or received to see how the story reflected the racism in America. It was done by relating the phenomenon indicating racism in the story with the phenomenon of racism happened in America.

\subsection{Method and Technique of Presenting Data}

This study applied informal method where the data was descriptively explained by using words and sentences. Furthermore, the data was presented with the analysis of the extrinsic elements that exposed in the novel "The Hate U Give" based on Wellek and Warren's extrinsic approach and how racism in America is reflected in the novel according to the sociological approach proposed by Laurensen and Swingwood.

\section{Analysis}

\subsection{The Synopsis "The Hate U Give"}

Sixteen years old Starr Carter has to live in two different worlds; Garden Height the poor black people neighborhood where she was born and raised and her fancy white people school Williamson in the suburbs. It was so difficult for her because she has to be two different persons in two different places. Her already complicated life becomes more complicated when she is the only witness of a police officer shoots his unarmed best-friend Khalil. The news becomes national issue and attracts many attentions especially when the folks know that Khalil is black and he is unarmed when the police officer shoots him.

Starr has to endure the pain of witnessing the injustice Khalil gets from their society because the people are more interested in Khalil's past rather than the fact that he is killed by a police officer. The media portrays Khalil as a gang banger and drug dealer, while more favorably portraying the white officer who kills him. Even the law is trying to make the police action justified by trying to find Khalil's mistakes.

Starr and her family have to face dangerous situation, especially when King and his gang get involved. She gets death threats, and someone shoots into her house. She is confused whether she 
has to tell the truth in order to get Khalil the justice he deserves or not because what she says could destroy her community. It could also get her killed.

\subsection{The Extrinsic Elements in the Novel "The Hate U Give"}

Extrinsic elements are the external factors that influence the creation of the literary work; it is the elements outside of the literary work itself. This study is aimed at analyzing the extrinsic factors that might influence the writer to write the novel based on the extrinsic approach proposed by Wellek and Warren. According to them there are five external factors that may influence the creation of a literary work, those are: biography of the author, the psychological aspect of the author, the society, ideas, and other arts.

\subsubsection{Biography}

Thomas writes the novel entitled "The Hate U Give" is very much influenced by her own experiences. It can be seen from the fact that many of the phenomenon happened in the novel was based on Thomas's experiences, especially in the life and characteristic of Starr Carter,

First, both Thomas and Starr are black and they are born and raised in the poor neighborhood known as the hood. Thomas is from Jackson, the capital city of Mississippi which is one of the cities in America that has the highest crime rates. Starr Carter in the story lives in a small city named Garden Height, a neighborhood notorious for gangs and drug dealers. Moreover, Thomas and Starr also attend the school most of the students are by white people that make them put up another personality. Thomas and Starr have to manage their attitude and behavior in their school in order to avoid the discrimination that may be given to them because of their color and race. Thomas and Starr learn how to be two different persons in two different places.

a. "I just have to be normal Starr at normal Williamson and have a normal day. That means flipping the switch in my brain so I'm Williamson Starr. Williamson Starr doesn't use slang-if a rapper would say it, she doesn't say it, even if her white friends do. Slang makes them cool. Slang makes her "hood." Williamson Starr holds her tongue when people piss her off so nobody will think she's the "angry black girl." Williamson Starr is approachable. No stank-eyes, side-eyes, none of that. Williamson Starr is nonconfrontational. Basically, Williamson Starr doesn't give anyone a reason to call her ghetto."

Data a shows how Starr tries to be different from how she used to be in Garden Heights, she makes a new version of herself, the Williamson Starr, who is completely different from the Starr in Garden Heights. In Williamson she speaks politely, she acts less aggressive; she behaves like how she thinks her fellow white friends will act. It also can be seen that Starr continuously mentions the "Williamson Starr" to emphasizes how different the characteristic of the "Garden Height Starr" and the "Williamson Starr".

\subsubsection{Psychology}

Thomas begin to write the short story that later becomes the best seller novel entitled "The Hate U Give" after the tragedy of Oscar Grant, an unarmed black man who is killed by police in Oakland California in 2008. In her interview with Politic and Prose Bookstore Thomas says that she is mad, hurt, and frustrated after hearing what the people at her school think about Oscar Grant, and it is all portrayed very well in her story. 
Thomas's feeling of being hurt is first shown in the book through the sorrow of Starr because of Khalil's death.

a. Back then I'd giggle behind my own snaggleteeth. Now I tear up. Goodbyes hurt the most when the other person's already gone. I imagine him standing at my window, and I smile for his sake. "After a while, crocodile."

In data a, it can be seen that Starr cannot help but recalls the old memory of her and Khalil when she is about to leave Khalil's house. She tears up when she remembers how Khalil will always run up to the car and says good bye in his own way. When she realizes she will never have that moment again, that he is already gone forever, and she will only be able to imagine him to be there hurts her so much like how Starr says that "Goodbyes hurt the most when the other person's already gone".

b. All my Williamson rules go out the door, and Starr from Garden Heights shows up. "What the fuck that got to do with it?"

Besides feeling hurt, Starr is also mad because her friends at her school use Khalil's death to get one free day at their school. She is angry to the point she does not even mind to curse at her school, something she always prohibits herself to do when she is at school. Starr has always tries to restraint herself to look like a black girl at her school. She even creates a new version of herself that only exists at Williamson in other to prevent the other students from calling her "ghetto". However, when the students use Khalil's death for their own advantage she cannot control herself, she lets the Garden Height Starr comes out and shows her anger to everyone.

c. Starr, think about this," Chris says. "That won't solve anything."

"And neither did talking!" I snap. "I did everything right, and it didn't make a fucking difference. I've gotten death threats, cops harassed my family, somebody shot into my house, all kinds of shit. And for what? Justice Khalil won't get? They don't give a fuck about us, so fine. I no longer give a fuck."

In data c, Starr who is mad because of the court decision to do not indict the police officer who has killed Khalil decides to join the riot, but Chris does not agree with it. When Starr decides to join the riot to show her anger and to get justice for Khalil, it is not only anger that can be seen in there but also frustration. The way Starr snaps at Chris and says that all things she has done is for nothing shows how frustrated she is. She has given them her witness, gotten death threats, cops harassed her family, somebody shot into her house, and other things that endanger her and people around her, but still Khalil does not get the justice he deserves. Her frustration has led her to make a decision to be a part of the riot; the fastest way for her to show her anger and to make her heard.

\subsubsection{Society}

Thomas is a part of the black community who is born and raised in the poor black neighborhood, in Jackson Mississippi, but goes to a private white people school. The inequality of her two worlds has inspired her to create two completely different societies on her very first novel; the poor neighborhood of Garden Height and the wealthier suburbs surrounding the city.

a. The sun sets. We're in the middle of saying grace over pot roast and potatoes when the first gunshots ring out. We open our eyes. Sekani flinches. I'm used to gunshots, but these are louder, faster. One barely sounds off before another's right behind it. "

On the night after Khalil's funeral, the situation in the Garden Height is getting worse, there are gunshots everywhere, but how Starr says that she is used to the gunshot indicates that it is something normal happens in Garden 
Height. Garden Height is described as the poor neighborhood, which has an unhealthy environment controlled by two hostile gangs, which are very dangerous.

b. I used to think the sun shone brighter out here in Uncle Carlos's neighborhood, but today it really doesthere's no smoke lingering, and the air is fresher. All the houses have two stories. Kids play on the sidewalks and in the big yards. There are lemonade stands, garage sales, and lots of joggers. Even with all that going on, it's real quiet

In data b, Starr describes Riverton Hill as a place that has a healthy environment where the air is fresh. She also mentions that children are able to play around the neighborhood which means that Riverton Hill is a very safe neighborhood. At the end Starr also says that it is a quiet place even with so many activities in the neighborhood unlike The Garden Height where gunshot is heard almost everyday.

\subsubsection{Ideas}

The philosophy of The Hate U Give is based mainly on the French philosophers of the Age of Enlightenment, VoltaIre, Rousseau, Montesquieu who advocates that men were born free and equal. The main idea of this philosophy is that everyone was born free and equal no matter to what race they belong or what colors they have, they should be equally treated as they have the same rights. The idea of this philosophy is not obviously mentioned in the novel, but is indirectly presented by Thomas who consistently shows the injustice the black people have to face because of their race in her novel. In the novel, she emphasizes the differences between the life of the black people and white people; their environment, circumstances and how they are treated by the society. a. "Right. Lack of opportunities," Daddy says. "Corporate America don't bring jobs to our communities, and they damn sure ain't quick to hire us.

In data a, Maverick, Starr's father explains to Starr how the black people are discriminated as they does not get the same opportunities as the white people in getting a job. Companies in America do not want to give them the job, and they are their last choice. It is proven by the fact that most of the black people in the story are middle to lower class people, and this because they cannot get a proper job to improve their economic condition.

\subsubsection{Other Arts}

Thomas certainly is one of many writers who gets her inspiration from other forms of art especially music. Her past as a teen rapper explains why several famous rappers, like Kendrick Lamar and Tupac Shakur, are continuously mentioned in the book. There are so many scenes in the story where their songs are played. The admiration Thomas has towards Tupac and his music has led her to entitle her very first novel based on the very famous "THUG LIFE" tattoo of Tupac.

The novel is entitled "The Hate U Give" in which every first alphabet of the words will form the word "THUG". "The Hate U Give" is also derived from the meaning of Tupac's "THUG LIFE" tattoo that actually stands for "the hate you give little infants fucks everybody". Tupac explains as meaning that what society feeds into youth has a way of coming back and affecting us all. In the novel the "THUG LIFE" is described through the anger and riots happened in the story as a protest from the black people due to the discrimination and injustice they have been faced, especially when Khalil is shot by police and does not get the justice he deserves. The hate the majority of the society has given to him screws everyone. 
a. Sirens wail outside. The news shows three patrol cars that have been set ablaze at the police precinct, about a five-minute drive away from us. A gas station near the freeway gets looted, and the owner, this Indian man, staggers around bloody, saying he didn't have anything to do with Khalil's death. A line of cops guard the Walmart on the east side.

My neighborhood is a war zone.

In data a, Starr describes the situation in Garden Height as a "war zone", it portrays how chaotic the situation is. A war will always disserve all of the parties involve, and the innocent people will end up being at the most disadvantage side, the Indian man in the data is one of the examples of an innocent person who is harmed even though he has nothing to do with the accident. Like how Tupac defines "THUG LIFE", the hate the police officer gives to Khalil has a way to affect all of them, because of his unreasonable action that costs Khalil his life the whole society has to face the consequence.

\subsection{Racism in America Reflected in the Novel}

Thomas writes the story of "The Hate U Give" based on the real situation of the racism in America where AfricanAmerican people or the Black people in America are still experiencing injustice because of their race either from individual or institution. She portrays the racism in America by giving realistic depiction based on the real phenomenon happen in America. The individual racism in the story is done by Hailey's father when he indirectly humiliates the Black people by addressing their neighborhood as "The Ghetto"

a. Hailey didn't come. Her dad didn't want her spending the night in "the ghetto." I overheard my parents say that.
When Starr invites Hailey and Maya to come to her house in Garden Height, Hailey's father does not allow her to come because he does not want her daughter to spend the night in "The Ghetto". "Ghetto" is a word uses to address a part of the city especially the slum area where the minority lives, the word is first used in Venice to describe part of the city where Jews was restricted and segregated. Hailey's father indirectly humiliates Starr's family also the other black people by addressing Garden Height as "The Ghetto". He indirectly says that Starr and the other black people in the story are poor people who live in slum and he will not allow her daughter to spend her time in that kind of place.

Thomas creates this situation where the black people are humiliated by the white people are based on the real situation of the African-American people in their everyday life; they are often mocked and looked down because of their race. Based on the survey that is conducted in 2017 for National Public Radio, Robert Johnson Foundation, and Harvard T.H. Chan School of Public Health, it is found that the majority of black people in America have experienced slurs and insensitive comments about their race. The result shows that more than a half of the samples that consist of 802 AfricanAmerican adults in America have reported that they are personally experiencing racial slur and people make negative assumptions and insensitive or offensive comments about their race.

In the novel "The Hate U Give" there are also found the systemic racism that is done by the police and companies. b. My parents haven't raised me to fear the police, just to be smart around them. They told me it's not smart to move while a cop has his back to you.

Khalil does. He comes to his door. It's not smart to make a sudden move. Khalil does. He opens the driver's door. 
“You okay, Starr-” Pow!

One. Khalil's body jerks. Blood splatters from his back. He holds on to the door to keep himself upright.

Pow!

Two. Khalil gasps.

Pow! Three.

Khalil looks at me, stunned.

He falls to the ground

Khalil does not follow the police officer's order to do not move when he goes back to his patrol car. Khalil wants to check Starr's condition when suddenly the police officer shoots him three times on his back. This action of the police is completely unreasonable when Khalil is unarmed and there is nothing suspicious found on his car. The sudden move Khalil makes to check on Starr does not give the police officer enough reason to fatally shoot him to dead. Angie Thomas writes this tragedy is based on a true event happened in 2009 in Oakland California when unarmed Oscar Grant, a twenty two years old African-American man, was fatally shot by the police officer.

In America, police violence and other mistreatments have been happening since years ago and it usually involves White-on-Black or White-on-Latino violence. This is proven by a social science study that analyzes 130 accounts of police brutality in several cities in America. The result shows that in these cases the targets of police malpractice are almost always black or Latino and more than ninety percent of the officers involve are white. There are many cases where Black people in America are brutally beaten to dead by white police officer. Data on police violence in America during the years 1920-1932 shows that substantially more than half of all African Americans killed by Whites are killed by white officers

c. "Right. Lack of opportunities," Daddy says. "Corporate America don't bring jobs to our communities, and they damn sure ain't quick to hire us."

Starr's father explains to her that their community does not have enough opportunity to get a job. Companies in America do not want to hire them, and if they do, they make sure that the AfricanAmerican people are their very last choice. This phenomenon is actually happens in America as the result of the survey for National Public Radio, Robert Johnson Foundation, and Harvard T.H. Chan School of Public Health in 2017 shows that more than half of the AfricanAmerican people who are asked about their experiences of having racism in applying job say that they are discriminated when they try to apply for a job.

\section{Conclusions}

Based on the analysis that has been conducted in the previous chapter there are two things that can be concluded in relation with the research question. First, the five extrinsic elements mentioned by Wellek and Warren namely; biography, psychology, society, ideas, and other forms of art were found attached in the novel. Moreover, those five extrinsic elements were proven to influence the author in creating the novel entitled "The Hate U Give".

Second, it is found that the novel "The Hate U Give" reflects both the racism that is done by individual or institution namely; police and companies. The racism is reflected through a realistic depiction which is created based on the real phenomenon in America. The individual racism is done by humiliating and discriminating the African-American people as inferior people. The AfricanAmerican people are often mocked by the white people who address them with humiliating terms. The African-American people are also the target of the police unnecessary force and brutality, the police tend to use excessive force and 
becomes more abusive when they are interacting with the Black people. The African-American people also experience discrimination when they are applying for job as most of the companies do not want to hire them because of their race.

\section{Bibliography}

2017. Discrimination in America: Experiences And Views Of African Americans. USA: National Public Radio.

Feagin. Joe R. 2014. Racist America: Roots, Current, and Future Reparations. New York: Routledge.

Laurenson, Diana. T, and Swingewood, Alan. 1972. The Sociology of Literature. New York: Harper Collins Distribution Services.

Thomas, Angie. 2017. Angie Thomas, "The Hate U Give". Politic and Prose Bookstore. USA. 42 mins.

Thomas, Angie. 2017. The Hate U Give. London: Walker Books Ltd,.

Wellek, Rene, and Austen Warren. 1977. Theory of Literature. New York: Harcourt, Brace and Company, Inc 